\title{
Original article \\ Bioturbational redistribution of Danian calcareous nannofossils in the uppermost Maastrichtian across the K-Pg boundary at Bidart, SW France ${ }^{\text {is }}$
}

\section{Remaniement par la bioturbation de nannofossiles calcaires daniens dans le Maestrichtien terminal autour de la limite C-Pg dans la coupe de Bidart (SO France)}

\author{
Francisco J. Rodríguez-Tovar ${ }^{\mathrm{a}, *}$, Alfred Uchman ${ }^{\mathrm{b}}$, Eustoquio Molina ${ }^{\mathrm{c}}$, Simonetta Monechi ${ }^{\mathrm{d}}$ \\ ${ }^{a}$ Departamento de Estratigrafía y Paleontología, Facultad de Ciencias, Universidad de Granada, 18002 Granada, Spain \\ ${ }^{\mathrm{b}}$ Institute of Geological Sciences, Jagiellonian University, 30063 Kraków, Poland \\ ${ }^{\mathrm{c}}$ Departamento de Ciencias de la Tierra, IUCA, Universidad de Zaragoza, C/Pedro Cerbuna n ${ }^{\circ}$ 12, 50009 Zaragoza, Spain \\ ${ }^{\mathrm{d}}$ Dipartimento di Scienze della Terra, Universitá di Firenze, Via Giorgio La pira 4, 50121 Firenze, Italy \\ Received 3 October 2009; accepted 30 March 2010 \\ Available online 21 July 2010
}

\begin{abstract}
In this paper we present the effects of different tracemakers on the redistribution of calcareous nannofossils throughout the K-Pg boundary at the Bidart section (SW France), along with their consequences for our knowledge of the K-Pg boundary event. Danian calcareous nannofossil assemblages are present in Maastrichtian samples due to infiltration into dark trace fossil infillings proceeding from the earliest Paleogene. This is evidenced by the appearance of abundant paleogene calcareous nannofossils just below the K-Pg boundary, showing the relevance of the trace fossil infillings in the context of the K-Pg boundary event.
\end{abstract}

(C) 2010 Elsevier Masson SAS. All rights reserved.

Keywords: Cretaceous-Paleogene boundary; Trace fossils; Calcareous nannofossils; Redistribution; Bidart section; SW France

\section{Résumé}

Dans cet article, nous présentons les effets des organismes bioturbateurs sur le remaniement de nannofossiles calcaires autour de la limite C-Pg dans la coupe de Bidart (SW France), ainsi que leurs conséquences pour la compréhension de l'événement de la limite C-Pg. Des assemblages de nannofossiles typiquement daniens sont présents dans des échantillons du Maestrichtien, remaniés par infiltration, dans des remplissages de couleur sombre de traces fossiles formées au début du Paléogène. Cela est montré par la présence d'abondants nannofossiles calcaires paléogènes juste sous la limite C-Pg, montrant tout l'intérêt de l'étude des remplissages de traces fossiles dans le contexte de l'événement de la limite C-Pg. (C) 2010 Elsevier Masson SAS. Tous droits réservés.

Mots clés : Limite Crétacé-Paléogène ; Traces fossiles ; Nannofossiles calcaires ; Remaniement ; Coupe de Bidart ; SO France

\section{Introduction}

The Cretaceous-Paleogene (K-Pg) boundary has been profusely studied, mainly due to the major biological crisis associated with it (see Koutsoukos, 2005; Molina et al., 2006; Kring, 2007 for recent reviews). The extinction pattern is still controversial, mainly supported by gradual or catastrophic

\footnotetext{
Corresponding editor: Fabienne Giraud.

* Corresponding author.

E-mail address: fjrtovar@ugr.es (F.J. Rodríguez-Tovar).
}

interpretations of the extinction of microorganisms, in which the existence of Danian taxa considered as survivors or reworked specimens must play a key role. This is especially true for the planktic calcareous organisms (foraminifers and calcareous nannofossils). Some authors interpret the presence of Maastrichtian taxa found in the Danian sediments as totally or partially reworked (e.g., Smit, 1990; Pospichal, 1994; Henriksson, 1996; Molina et al., 1998; Tantawy, 2003; Gallala et al., 2009), while others suggest that some Maastrichtian taxa survived the disaster but disappeared in the earliest Danian (e.g., Perch-Nielsen et al., 1982; Keller, 1988; Keller et al., 1995; Gardin and Monechi, 1998; Gardin, 2002; Bown, 2005). 
Due to their very small size, calcareous nannofossils are comparatively easily resedimented and reworked. This fact has been brought forth in several papers on the K-Pg boundary, showing Cretaceous taxa in Danian samples and vice versa; but only occasionally has the incidence of the activity of tracemakers on calcareous nannofossils redistribution been considered, and in almost all cases this aspect has been alluded to in general terms (e.g., Thierstein and Okada, 1979; Thierstein, 1981; Smit and Romein, 1985; Pospichal and Wise, 1990; Pospichal et al., 1990; Henriksson, 1996; Pospichal, 1996; Romein et al., 1996; Mai et al., 2003; Bown, 2005; Lamolda et al., 2005). Thus, the role of tracemakers in the reworking of microfossils is usually underestimated. It has recently been demonstrated, however, that trace fossils throughout the K-Pg boundary interval are relatively abundant and diverse, colonizing lower Danian sediments and penetrating the light Maastrichtian marlstones (Rodríguez-Tovar and Uchman, 2004, 2008; Rodríguez-Tovar et al., 2004; Rodríguez-Tovar, 2005).

The K-Pg boundary section at Bidart is held to be a key section for interpreting the K-Pg boundary event (Galbrun and Gardin, 2004). Very recent planktic foraminifera analysis suggests a sudden catastrophic mass extinction at the K-Pg boundary affecting at least 53 species (Gallala et al., 2009). However, infiltration is difficult to identify in planktic foraminifera due to the scarcity and small size of the basal Danian species, which are difficult to find among the highly diversified and large foraminifera of the Maastrichtian assemblages, mainly because of the small quantity of sediment available from the trace fossil infilling. With respect to calcareous nannofossils throughout the K-Pg boundary interval at the Bidart section, meanwhile, detailed work and numerous papers have been published (e.g., Perch-Nielsen, 1979; Gorostidi and Lamolda, 1995; Minoletti et al., 2004, 2005). Taphonomic analysis of the calcareous nannofossils reveals the presence of "Maastrichtian-like calcareous nannofossils" in the lowermost Danian sediments (Minoletti et al., 2005). These are nannofossil taxa that indisputably occur in the Maastrichtian, but do not occur consistently in later Danian strata; and although the isotopic signature strongly suggests that, at least at Bidart, they are mainly reworked from the Maastrichtian, neither data nor interpretations about the possible causes of this reworking have been put forth (Minoletti et al., 2004,2005 ) and infiltration has not been specified.

In this paper we present a detailed analysis of the trace fossil infillings from the K-Pg boundary interval at the Bidart section, focusing on the relationship between the different ichnotaxa and the calcareous nannofossil redistribution, as well as their relevance for interpretation of the K-Pg boundary event.

\section{Geological setting}

The Bidart section is located between Hendaya and Biarritz (south-western France), in the Basque-Cantabric Basin (Fig. 1), cropping out along a beach a few kilometres long towards the north at Bidart $\left(43^{\circ} 27^{\prime} \mathrm{N}\right.$ and $\left.1^{\circ} 35^{\prime} \mathrm{E}\right)$. The magnetostratigraphy and biostratigraphy of the Cretaceous-Tertiary boundary of Bidart was established by Delacotte et al. (1985). From a

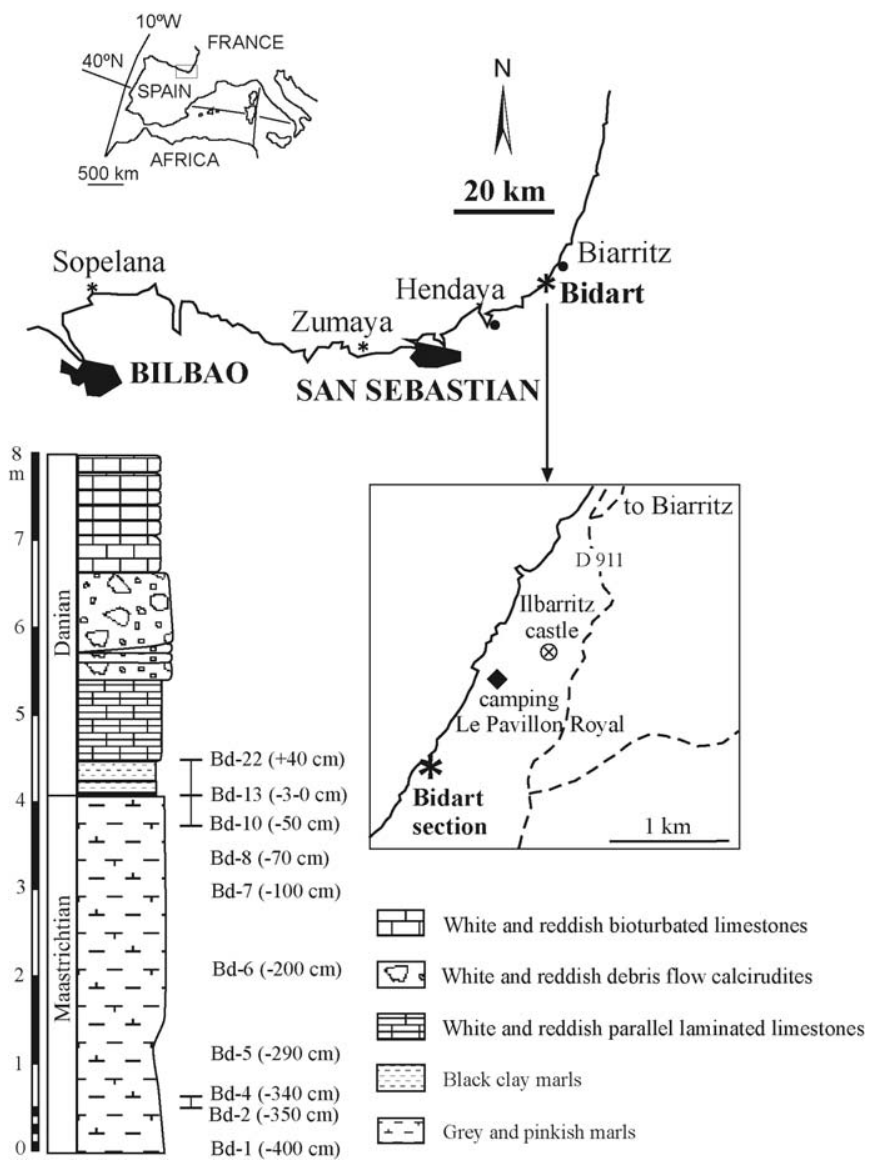

Fig. 1. Location of the Bidart section between Hendaya and Biarritz (southwestern France), and other important K-Pg boundary sections (Zumaya and Sopelana), and general stratigraphic column from the upper Maastrichtian to the lower Danian with location of the studied samples.

palaeogeographic point of view, the K-Pg boundary sections of the Basque Basin are located in a deep-basin environment, between 800 and $2.000 \mathrm{~m}$ depth (Orue-Etxebarría et al., 1996; Apellániz et al., 1997; Pujalte et al., 1998), with a dominant pelagic and/or hemipelagic sedimentation, showing local turbidites (Apellániz et al., 1997). The Bidart section is believed to be situated in close proximity to a palaeoslope to the northeast (Seyve, 1984), in a distal deep-sea fan environment with a $40 \mathrm{~mm} / \mathrm{ky}$ sedimentation rate during the Maastrichtian (Nelson et al., 1991), showing increased activity on the slope - slumped blocks and turbidites are registered - during the Paleocene (Seyve, 1990). The study of benthic foraminifera points to the upper-middle part of the slope for sediment deposition at the Bidart section from the upper Maastrichtian to the lower Danian (Alegret et al., 2004). The palaeogeographic situation is particularly interesting, between the Tethys and the North Atlantic, showing a change in deposition influences from Tethyan during Maastrichtian, then to primarily North Atlantic during the Paleocene (Renard et al., 1982). Benthic foraminiferal assemblages reveal significant palaeoenvironmental changes throughout the K-Pg boundary interval, showing mesotrophic conditions during the late Maastrichtian and sufficient nutrient supply to the sea-bottom floor to sustain both infaunal and epifaunal morphogroups, with a strong decrease in food supply to 
the sea floor at the K-Pg boundary (Alegret et al., 2004). This food supply was not completely recovered for over $200 \mathrm{kyr}$, at least, after the K-Pg boundary (Alegret et al., 2004).

The planktic foraminiferal assemblage across the K-Pg boundary is highly diversified, containing up to 72 species, and with a catastrophic sudden mass extinction affecting at least 53 out of these species (Gallala et al., 2009). The K-Pg boundary extinct species include globotruncanids (e.g., Contusotruncana spp., Globotruncana spp., Globotruncanita spp.) and complex heterohelicids (e.g., Racemiguembelina spp., Pseudotextularia spp., Gublerina spp.). Specimens of 18 Maastrichtian species, small and even tiny in size, were found at the lowermost Danian. Few of these species belong to Guembelitria or Hedbergella, and it is likely that Heterohelix is the only real Cretaceous survivor species. Contrariwise, the specimens belonging to the rest of the 14 species (mainly Heterohelix, Pseudoguembelina, Globotrumcanella and some species of Rugoglobigerina and Globotruncana) seem to be reworked, according to their different taphonomic preservation (mainly different colour and fragmentation).

\section{Material and method}

The K-Pg boundary transition was studied at the Bidart section. The upper $4 \mathrm{~m}$ of the Maastrichtian contain grey and pinkish marls and marly limestones (Figs. 1 and 2). The K-Pg boundary is easily identifiable at the base of the boundary layer; a "rusty" layer, about $2 \mathrm{~mm}$ thick, is characterized by an Ir anomaly. Above the "rusty layer", at the base of the Danian, a dark clay layer about $15 \mathrm{~cm}$ thick occurs, overlapped by about $23 \mathrm{~cm}$ of marls and marly limestones, which are reddish brown in the middle part of the layer and green and partly laminated towards the top. Above them, a $93 \mathrm{~cm}$ thick interval of white and reddish, partly parallel laminated limestones is present, followed by a few beds of white and reddish debris flow beds mostly made up of calcirudites. At the top of this interval the studied section consists of white and reddish bioturbated limestones. Continuous bed-by-bed detailed ichnological analysis was conducted $4 \mathrm{~m}$ below and above the K-Pg boundary, focusing on recognition of ichnotaxa and their vertical distribution, type of filling, cross-cutting relationships, ichnofabrics and other features. Moreover, isolated samples were collected for ichnological analysis in the laboratory.

Calcareous nannofossils from sediments hosting trace fossils were analyzed in a span of about $5 \mathrm{~m}$ across the $\mathrm{K}$ Pg boundary transition: $4 \mathrm{~m}$ in the uppermost Maastrichtian and $40 \mathrm{~cm}$ of the lowest part of the Paleogene (Figs. 1 and 2). Below the K-Pg boundary surface, samples were collected at $-400 \mathrm{~cm}$ (Bd-1), $-200 \mathrm{~cm}$ (Bd-6), $-40 \mathrm{~cm}$ (Bd-11), $-35 \mathrm{~cm}$ (Bd-9), and $-3-0 \mathrm{~cm}(\mathrm{Bd}-13)$. Above the $\mathrm{K}-\mathrm{Pg}$ boundary surface, $\mathrm{Bd}-14$ is located just above the boundary, and Bd-15, Bd-17, Bd-19 and Bd-22 are located at 6, 17,29 and $40 \mathrm{~cm}$, respectively. Analyses were focused on trace fossils filled with a dark-coloured sediment similar to that of the lowermost Danian marls and occasionally on light-coloured burrows occurring below the K-

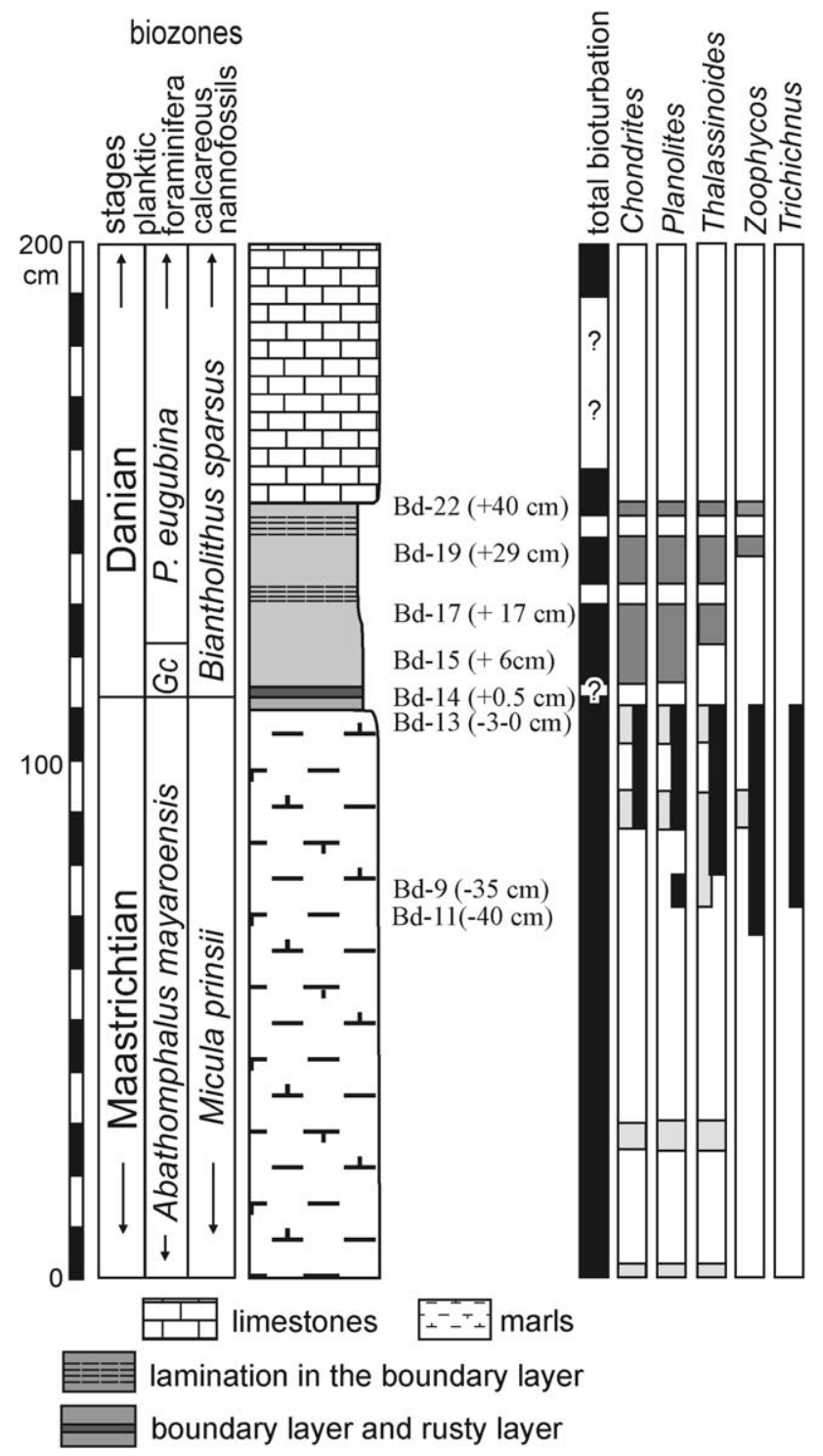

Fig. 2. Stratigraphic column of the K-Pg boundary interval in the Bidart section, with location of the selected samples, and indication of ranges of trace fossils. Trace fossil ranges: black colour refers to trace fossils filled with sediment from the dark boundary layer, registered in the Maastrichtian sediments; dark-grey colour refers to trace fossils filled with material from the dark boundary layer, registered in the Danian sediments; light-grey colour refers to trace fossils filled with light material from the Maastrichtian sediments. Total bioturbation refers to totally bioturbated background. Gc: Guembelitria cretacea; P. eugubina: Parvularugoglobigerina eugubina.

Pg boundary. Samples were selected on the basis of the type and size of trace fossils, and consequent possibilities for analyzing the filling material, location and depth of penetration; thus only Thalassinoides and Zoophycos structures were considered. Present in Bd-9 were dark Thalassinoides (Bd-9 dft), in Bd-11 dark Zoophycos (Bd-11 dfz), and in Bd-13 dark (Bd-13 dft) and light Thalassinoides (Bd-13 lft).

Samples for nannofossil investigation were prepared as follow: a small chip of sediment has been powdered and add distilled water. Few drops of the mixture were then spread on a coverslip and dried. The coverslip were glued on the glass slide 
with a drop of Norland optical Adhesive (NOA-65). Unprocessed material was used in order to avoid mechanical and physical processes that could modify the original composition of the assemblages. The calcareous nannofossils were analyzed under a Zeiss Axioplan2 petrographic microscope at $\times 1560$ magnification. Qualitative analyses have been performed on the studied samples in order to characterize the assemblage and at least three traverses of the slides were examined to find rare taxa.

Several detailed calcareous nannofossil studies describe the K-Pg transition of Bidart (Gorostidi and Lamolda, 1995 and reference therein; Galbrun and Gardin, 2004; Thibault et al., 2004; Minoletti et al., 2005). We refer to these papers for the complete biostratigraphic zonation, distribution and exhaustive palaeoecological calcareous nannofossil changes across the KPg boundary interval.

\section{Results}

\subsection{Trace fossil assemblage}

Relatively abundant and conspicuous dark-coloured trace fossils occur throughout the studied interval, including Chondrites, Planolites, Thalassinoides, Trichichnus and Zoophycos (Fig. 2), on totally bioturbated sediment background related to the activity of unknown organisms in the uppermost part of the substrate. Less abundant light-coloured ichnofossils include Planolites and Thalassinoides.

Chondrites isp. is observed mostly in cross section as patches of circular to elliptical spots and short bars, which some of them are branched, filled with a darker material than the surrounding rock. They are cross sections of a branched tubular burrow system. A larger form, 2-3 mm in diameter, and smaller form, up to $1 \mathrm{~mm}$ diameter, can be distinguished. Limited observations along the tunnels preclude more detailed determinations, however taking into account the size parameters (Uchman, 1999), the smaller form can belong to Chondrites intricatus (Brongniart, 1823) and the larger one to Chondrites targionii (Brongniart, 1828). The smaller form can be found in the fillings of some Thalassinoides or Planolites.

Chondrites von Sternberg, 1833 is a feeding system of unknown trace makers (Osgood, 1970) which, according to Kotake (1991a), are surface ingestors, packing their faecal pellets inside burrows. According to Seilacher $(1990,2007)$ and Fu (1991), the tracemaker may be able to live at the aerobicanoxic interface as a chemosymbiotic organism. Chondrites shows a wide stratigraphic and marine environmental range.

Planolites isp. occurs as horizontal to oblique, straight to slightly winding, simple flattened cylinders, $2.5-4 \mathrm{~mm}$, without lining. They are filled with dark grey fine-grained material.

Planolites is a facies crossing form. It has been discussed by Pemberton and Frey (1982) and Keighley and Pickerill (1995) and interpreted as a pascichnion, probably produced by a number of different organisms.

Thalassinoides isp. is registered as straight or slightly winding, horizontal to oblique flattened, unlined cylinders, showing Y-shaped branches and shafts, filled with homogenous, or rarely meniscate, mostly darker sediment. The cylinders are swollen at the branching points. Smaller forms are 5-9 $\mathrm{mm}$ in diameter, with swellings up to $15 \mathrm{~mm}$ wide. Some forms, especially in the Danian, are larger, $15-25 \mathrm{~mm}$ in diameter, which swellings are up to $35 \mathrm{~mm}$ wide.

Thalassinoides Ehrenberg, 1944 is a domichnial and fodinichnial structure produced by crustaceans, mostly decapods (Frey et al., 1984). It occurs in a great variety of marine environments, yet is most typical for the shelf Cruziana ichnofacies. For further discussion of this ichnogenus and its ichnotaxonomic problems see Fürsich (1973), Ekdale (1992) and Schlirf (2000).

Trichichnus isp. is a winding or straight, differently oriented, rarely branched, $0.2-0.3 \mathrm{~mm}$ thick, thread-like cylinder filled with ferruginous substance, with a yellowish halo around the cylinder.

Trichichnus Frey, 1970 is a eurybathic marine trace fossil, which is common in fine-grained sediments. Its filling displays a strong tendency to pyritization (e.g., Werner and Wetzel, 1981; McBride and Picard, 1991). Trichichnus is regarded as the domichnial burrows of marine meiofaunal deposit-feeders (Frey, 1970). Possibly, the producer of Trichichnus was a chemosymbiont (Uchman, 1995), as in the case of the Chondrites producer (Seilacher, 1990; Fu, 1991). McBride and Picard (1991) suggest that Trichichnus had a more opportunistic character than Chondrites because it occurs more deeply in very poorly oxygenated sediments. For taxonomic discussion see Uchman (1999).

Zoophycos isp. occurs on parting surfaces as horizontal or oblique lobes and tongues, up to $40 \mathrm{~cm}$ wide, filled with spreite laminae encircled by a thin marginal tunnel, which are a part of a helical burrow system. In cross section it is seen as stacked stripes, $1.5-3 \mathrm{~mm}$ thick, which can be massive or filled with spreite manifested on the surface as menisci-like structures.

Zoophycos s.l. is generally considered as a structure produced by some yet undiscovered deposit-feeder, which is referred to as sipunculids (Wetzel and Werner, 1981; Olivero and Gaillard, 2007), polychaete annelids, arthropods (Ekdale and Lewis, 1991), or echiuran worms (Kotake, 1992). Kotake (1989, 1991b) showed that Zoophycos is produced by surface ingestors of organic detritus. The precise ethological interpretation of Zoophycos remains controversial. This is probably due to the assignment to Zoophycos s.l. of diverse structures generated by different tracemakers with different behaviour, or even a single tracemaker with diverse behaviours (Kotake, 1989, 1994; Bromley, 1991; Locklair and Savrda, 1998; MacEachern and Burton, 2000; Olivero and Gaillard, 2007). Bromley and Hanken (2003) suggested that the upper helical part of a large Pliocene Zoophycos from Rhodes, Greece, is a deposit-feeding structure, and lateral lobes developing from its lower part are sulphide wells for chemosymbiotic bacteria. The same interpretation refers to a similar but smaller Zoophycos from the Miocene of Austria, which displays very steep lobes in its lowermost part (Pervesler and Uchman, 2004).

The lower Danian dark-coloured trace fossil assemblage vertically penetrates the upper $40 \mathrm{~cm}$ of the light Maastrichtian 
marlstones (Fig. 2). Large dark-coloured Zoophycos isp. occurs at $-40 \mathrm{~cm}$ from the K-Pg boundary surface. Chondrites, Planolites, and Thalassinoides are recorded more or less continuously from the K-Pg boundary surface up to $-35 \mathrm{~cm}$. In the first $8 \mathrm{~cm}$ of the Danian sediments, trace fossils are difficult to distinguish; dark-filled trace fossils present similarly coloured sediment in this part of the succession. The higher part of the lowest Danian is totally bioturbated, except for a thin $(1.5 \mathrm{~cm})$ parallel laminated layer at the level of about $+18 \mathrm{~cm}$. The bioturbated sediments show the same ichnotaxa as below the boundary.

\subsection{Calcareous nannofossil assemblages in the}

Maastrichtian and Danian sediment surrounding trace fossils

Samples from the Maastrichtian sediments, Bd-1 $(-400 \mathrm{~cm})$, Bd-6 $(-200 \mathrm{~cm}), \mathrm{Bd}-11(-40 \mathrm{~cm}), \mathrm{Bd}-9(-35 \mathrm{~cm})$, and Bd13 (at-3-0 cm), show the classical latest Maastrichtian calcareous nannofossil assemblage of the Micula prinsii Zone (Gorostidi and Lamolda, 1995; Galbrun and Gardin, 2004; Minoletti et al., 2005). The assemblage is abundant, moderately preserved and highly diversified (Figs. 3-5). The most common

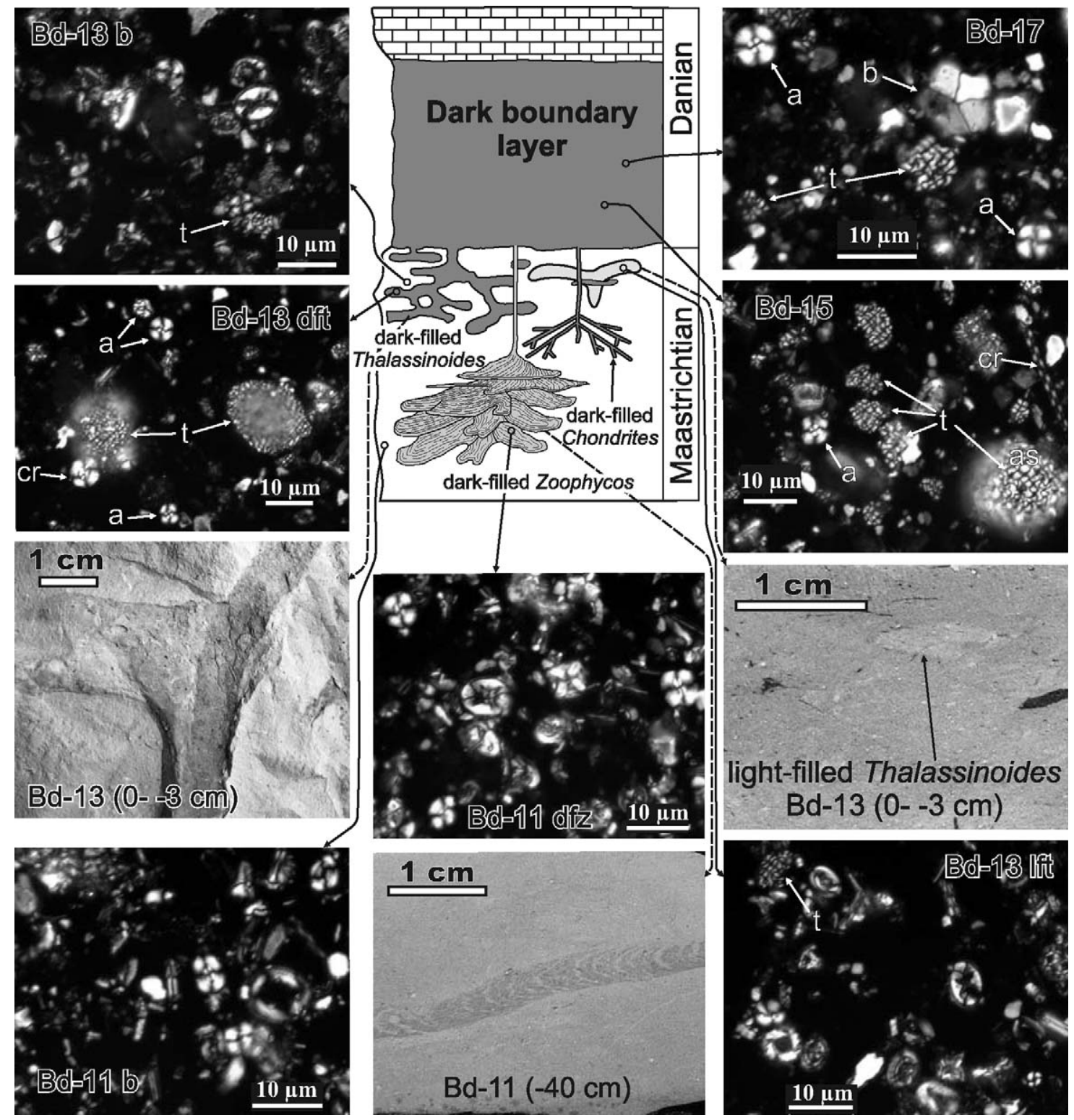

Fig. 3. Distribution and images of the trace fossils and calcareous nannofossils (at crossed polarized light) from the K-Pg boundary interval at Bidart. Sample Bd-13 b - background sedimentation: Cretaceous nannofossil assemblage with a few specimens of Operculodinella spp. Sample Bd-13 dft - dark-filled Thalassinoides: nannofossil assemblage similar to sample Bd-15 with Operculodinella spp., C. reinhardtii and few Cretaceous species. Bd-11 b - background sedimentation: Cretaceous nannofossil assemblage. Sample Bd-11 dfz - dark-filled Zoophycos: Cretaceous nannofossil assemblage. Sample Bd-13 lft - light-filled Thalassinoides: Cretaceous assemblage with fragments of Operculodinella spp. Sample Bd-15 - Danian sediments: Danian nannofossil assemblage with Operculodinella spp., C. reinhardtii and a few Cretaceous species. Sample Bd-17 - Danian sediment: Danian nannofossil assemblage with Braarudosphaera spp., Operculodinella spp. and $C$. reinhardtii. Abbreviations: a, Cyclagelosphaera reinhardtii; as, Cretaceous assemblage; b, Braarudosphaera bigelowii; cr, Cretaceous species; t, Operculodinella (= Thoracosphaera) spp. 

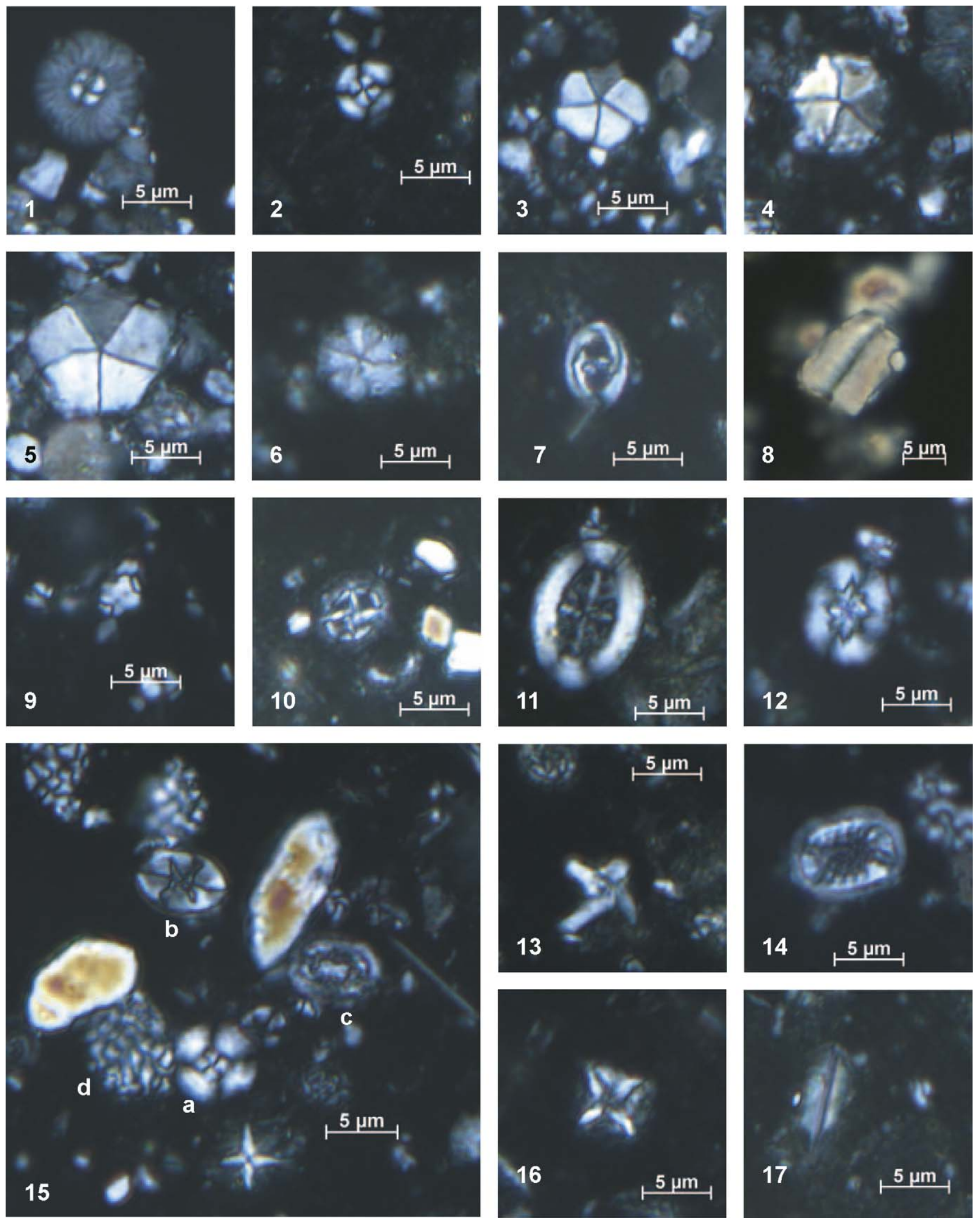

Fig. 4. Microscope pictures of selected nannofossil species from the Bidart section. 1. Markalius inversus (Bd-17). 2. Cyclagelosphaera alta (Bd-14). 3. Braarudosphaera cf. discula (Bd-17). 4. Braarudosphaera alta (same magnification than Fig. 8; Bd-19). 5. B. bigelowii (Bd-17). 6. Biantholithus sparsus (Bd-14). 7. Placozygus fibuliformis (Bd-13 dft). 8. B. alta (lateral view; Bd-22). 9. Octolithus multiplus (Bd-17). 10. Prediscosphaera cretacea (Bd-14). 11. Arkhangelskiella cymbiformis (Bd14). 12. Retacapsa angustiforata (Bd-13 dft). 13. Micula prinsii (Bd-14). 14. Cribrosphaerella ehrenbergii (Bd-13 dft). 15. a. Cyclagelosphaera reinhardtii, b. Eiffellithus turriseiffelii, c. Cribrosphaerella ehrenbergii, d. Operculodinella spp. (Bd-13 dft). 16. Micula decussata (Bd-14). 17. Lithraphidites quadratus (Bd-14). 


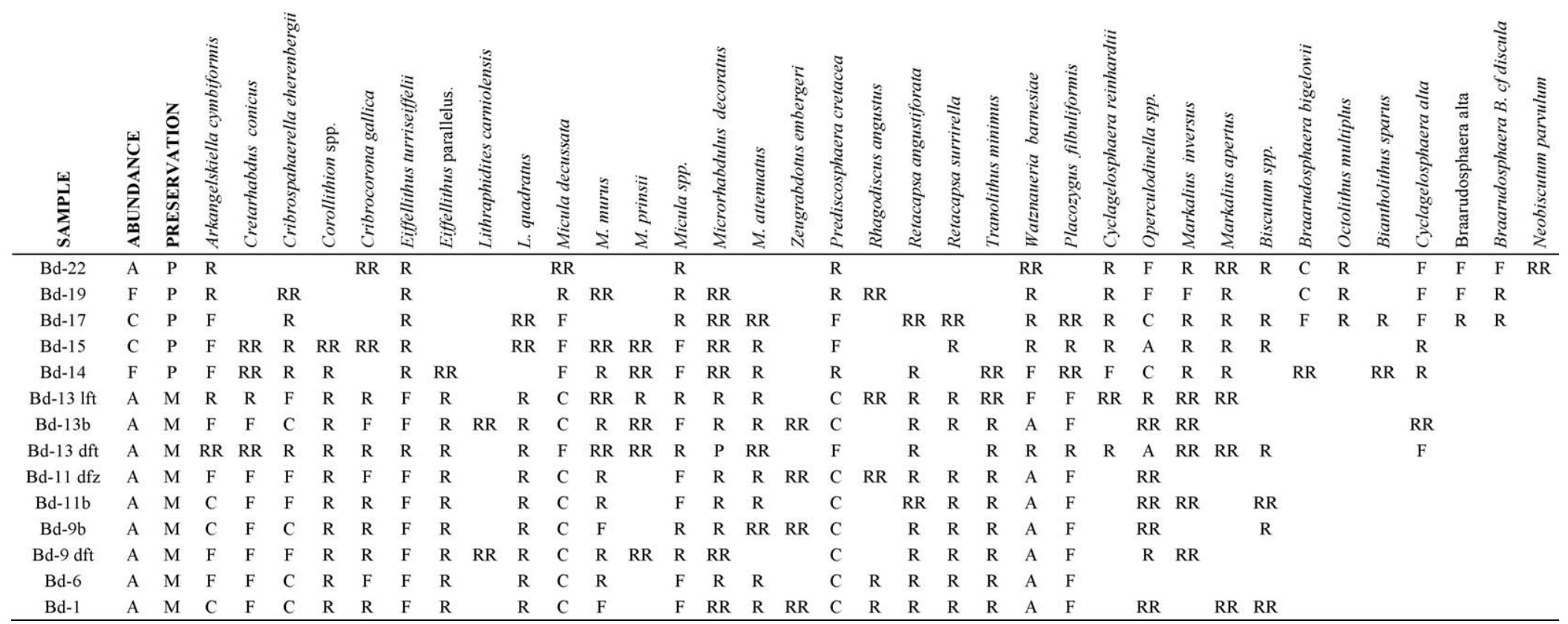

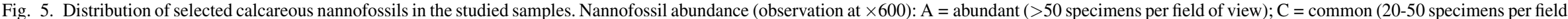

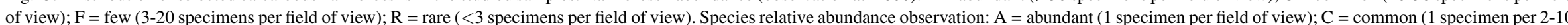
fields of view); $\mathrm{F}=$ few $(1$ specimen per 11-20 fields of view $) ; \mathrm{R}=$ rare $(1$ specimen per $21-50$ fields of view); $\mathrm{RR}=$ very rare $(1$ specimen per $>50$ fields of view $)$. Preservation: $\mathrm{P}=$ poor; $\mathrm{M}=$ moderate. 
taxa are Watznaueria barnesiae, Prediscosphaera cretacea, Cribrosphaerella ehrenbergii, Arkhangelskiella cymbiformis, Micula group (M. decussata, M. concava, M. murus), Lithraphidites quadratus, Eiffellithus turriseiffeli, E. parallelus, Cribrocorona gallica and Microrhabdulus decoratus. In samples Bd-9 and Bd-11, very rare pieces of the calcareous dinocyst Operculodinella operculata (= Thoracosphaera operculata of previous authors) were recognized, while in Bd-13 we observed a few forms of Operculodinella spp., together with very rare Cyclagelosphaera reinhardtii, Markalius inversus and $M$. apertus. In sample Bd-14 (Fig. 5), just above the K-Pg boundary a change in the calcareous nannofossil assemblage is observed: Operculodinella increased in abundance, and Biantholithus sparsus and Cyclagelosphaera reinhardtii are present, together with the most common Maastrichtian taxa. A decrease in the abundance is observed together with carbonate fragments. Following the suggestion of Mai et al. (2003) and Bernaola and Monechi (2007), in order to unambiguously identify the basal Danian, the occurrence of the index species B. sparsus was used. It should be underlined that in these samples the preservation of the Cretaceous species is moderately good, especially for $A$. cymbiformis and M.prinsii. This is also recognized in other K-Pg boundary sections, as in the Site 1262 (Bernaola and Monechi, 2007).

The following samples above the K-Pg boundary surface show a succession of abundant assemblages dominated by opportunistic forms (Fig. 3). The first sample, corresponding to Bd-15 (+6 cm), is characterized by abundant Operculodinella associated with $M$. inversus, $M$. apertus, $C$. reinhardtii, C. alta and few Maastrichtian taxa. Operculodinella operculata (calcareous dinoflagellate) represents a persistent taxon, surviving the K-Pg boundary, and the increase in abundance of this form reflects ecological stress after the rapid environmental changes at the boundary (Hildebrandt-Habel et al., 1999). The second appearance, in samples Bd$17(+17 \mathrm{~cm}), \quad \mathrm{Bd}-19(+29 \mathrm{~cm})$ and $\mathrm{Bd}-22(+40 \mathrm{~cm})$, is characterized by an increased abundance of Braarudosphaera bigelowii and $B$. alta, displacing Operculodinella; the assemblage mainly consists of Octolithus multiplus, $M$. inversus, $M$. apertus, C. alta, $C$. reinhardtii and a few Maastrichtian taxa.

\subsection{Calcareous nannofossils from the trace fossil infillings}

Dark-filled Thalassinoides from Bd-9 shows an assemblage characterized by common Maastrichtian taxa and the presence of Operculodinella spp., M. inversus, and B. sparsus (?). In sample Bd-9, from the surrounding sediments, only very rare Operculodinella are recognized. Dark-filled Zoophycos from Bd-11 shows an assemblage of Maastrichtian taxa with very rare $M$. inversus. This assemblage is quite similar to that from the sediments surrounding trace fossils of samples Bd-9 and Bd-11 (Fig. 3). Dark-filled Thalassinoides from Bd-13 shows an assemblage of abundant Operculodinella (= Thoracosphaera) associated with $M$. inversus, M. apertus, $C$. reinhardtii and a few Maastrichtian taxa (Fig. 5). This assemblage is very different from that of the surrounding Cretaceous sediments of sample Bd-13, in which Maastrichtian taxa are predominant (Fig. 5). The dark-filled Thalassinoides shows the same assemblage as sample Bd-15.

Light-filled Thalassinoides from Bd-13 shows an assemblage quite similar to the normal sedimentation of $\mathrm{Bd}-13$, mainly characterized by Maastrichtian taxa with a few Operculodinella (= Thoracosphaera), C. reinhardtii and $M$. inversus (Fig. 3).

\section{Discussion and conclusions}

Only occasionally have trace fossils or bioturbational structures been mentioned in the $\mathrm{K}-\mathrm{Pg}$ boundary section at Bidart (Smit and Ten Kate, 1982; Haslett, 1994; Gorostidi and Lamolda, 1995), without reference to a possible dislocation of microfossils by bioturbation (Nelson et al., 1991). Notwithstanding, analysis of calcareous nannofossil assemblages from the infillings of trace fossils and surrounding sediment would appear especially significant (Fig. 3). The calcareous nannofossil assemblages of the dark-filled Thalassinoides from samples $\mathrm{Bd}-9(-35 \mathrm{~cm})$ and $\mathrm{Bd}-13(-3-0 \mathrm{~cm})$ are very different from those of the surrounding uppermost Maastrichtian sediment, while similar to ones from sample Bd-15 $(6 \mathrm{~cm}$ above the K-Pg boundary; lowermost Danian). The calcareous nannofossil assemblages of the dark-filled Zoophycos and lightfilled Thalassinoides from samples Bd-11 (-40 cm) and Bd-13, respectively, show a similar composition to those from the surrounding uppermost Maastrichtian sediment. These data confirm the existence of two phases of macro-benthic colonization:

- the pre-K-Pg boundary event colonization phase, represented by the light-filled Thalassinoides, showing an infilling nannofossil assemblage composition similar to that of the surrounding sediment;

- the post-K-Pg boundary colonization phase, represented by dark-filled Thalassinoides and Zoophycos, where Thalassinoides displays a nannofossil assemblage similar to the one from the lowermost Danian (characterized by abundant Operculodinella [= Thoracosphaera], $C$. reinhardtii and $M$. inversus).

Yet this is not the case for Zoophycos. The difference between the nannofossil assemblages from the dark-filled Thalassinoides and dark-filled Zoophycos is related to the formation of these trace fossils; while Thalassinoides is commonly interpreted as an open burrow passively filled by the overlying sediment (Bromley, 1996), the origin of Zoophycos remains controversial (Löwemark et al., 2004), the infilling being a large admixture of the in situ material.

Especially relevant is the good preservation of the nannofossil assemblages described here, with no significant differences found between those from the surrounding sediment and the Thalassinoides infillings, either dark or light. This comes to support the general interpretation of Thalassinoides as passively filled burrows, precluding any secondary modification of the infilling due to activity of the tracemaker. Thus, 
taphonomic features per se are not conclusive evidence of infiltration of the nannofossil specimens.

The story told by the Bidart section, as understood in the context of the present and other recent studies, comprises the following:

- a recognition of the reworking of Maastrichtian calcareous nannofossils within lowermost Danian sediments related to the drastic extinction event at the K-Pg boundary;

- patterns of abundance of the calcareous nannofossils species from passively filled burrows of the topmost Maastrichtian would lower the position of the earliest large occurrence of Danian calcareous nannofossils (such as Operculodinella), leading one to misinterpret the K-Pg biotic turnover.

This evidence shows that the distribution of calcareous nannofossils in the Bidart section can be strongly dependent on the occurrence of particular ichnotaxa. Thus, we have to reconsider our knowledge on the K-Pg turnover event in a new light. The K-Pg reference sections should be re-analyzed for the presence of trace fossils with passive infilling (such as Thalassinoides) with respect to micropaleontological assemblages.

\section{Acknowledgements}

We thank Prof. Christian Gaillard (University Claude Bernard Lyon 1, France), Dr. Nicolas Thibault (University of Copenhagen), and the journal Associate Editor (Dr. Fabienne Giraud) for valuable suggestions and comments on the previous version of the manuscript. The research was supported by projects CGL2005-01316/BTE, CGL-2007-63724, CGL200803007/CLI, RNM-3715, and Murst-PRIN 2007, and by the RNM-178 group. A.U. received additional support from the Jagiellonian University in Krakow (DS812). We thank Dr. Silvia Gardin (Univ. Paris 6) for discussions and comments.

\section{References}

Alegret, L., Kaminski, M.A., Molina, E., 2004. Paleoenvironmental recovery after the Cretaceous/Paleogene boundary crisis: evidence from the Marine Bidart section (SW France). Palaios 19, 574-586.

Apellániz, E., Baceta, J.I., Bernaola-Bilbao, G., Núñez-Betelu, K., OrueEtxebarría, X., Payros, A., Pujalte, V., Robin, E., Rocchia, R., 1997. Analysis of uppermost Cretaceous-lowermost Tertiary hemipelagic successions in the Basque Country (western Pyrenees): evidence for a sudden extinction of more than half planktic foraminifer species at the $\mathrm{K} / \mathrm{T}$ boundary. Bulletin de la Société géologique de France 168, 783-793.

Bernaola, G., Monechi, S., 2007. Calcareous nannofossil extinction and survivorship across the Cretaceous-Paleogene boundary at Walvis Ridge (ODP Hole 1262C, South Atlantic Ocean). Palaeogeography, Palaeoclimatology, Palaeoecology 255, 132-156.

Bown, P., 2005. Selective calcareous nannoplankton survivorship at the Cretaceous-Tertiary boundary. Geology 33, 653-656.

Bromley, R.G., 1991. Zoophycos: strip mine, refuse dump, cache or sewage farm? Lethaia 24, 460-462.

Bromley, R.G., 1996. Trace Fossils. Biology, Taphonomy and Applications. Chapman and Hall, London.

Bromley, R.G., Hanken, N.M., 2003. Structure and function of large, lobed Zoophycos, Pliocene of Rhodes, Greece. Palaeogeography, Palaeoclimatology, Palaeoecology 192, 79-100.
Brongniart, A.T., 1823. Observations sur les Fucoïdes. Société d'Histoire Naturelle de Paris Mémoire 1, 301-320.

Brongniart, A.T., 1828. Histoire des végétaux fossiles ou recherches botaniques et géologiques sur les végétaux renfermés dans les diverses couches du globe, volume 1. G. Dufour et E. d'Ocagne, Paris.

Delacotte, O., Renard, M., Laj, C., Perch-Nielsen, K., Premoli Silva, I., Clauser, S., 1985. Magnétostratigraphie et biostratigraphie du passage CrétacéTertiaire de la coupe de Bidart (Pyrénées Atlantiques). Bulletin de la Société géologique de France (8) 3, 243-254.

Ehrenberg, K., 1944. Ergänzende Bemerkungen zu den seinerzeit aus dem Miozän von Burgschleinitz beschrieben Gangkernen und Bauten dekapoder Krebse. Paläontologische Zeitschrift 23, 345-359.

Ekdale, A.A., 1992. Muckraking and mudslinging: the joys of deposit-feeding. In: Maples, C.G., West, R.R. (Eds.), Trace fossils. Paleontological Society, Short Courses in Paleontology 5, pp. 145-171.

Ekdale, A.A., Lewis, D.W., 1991. The New Zealand Zoophycos revisited. Ichnos 1, 183-194.

Frey, R.W., 1970. Trace fossils of Fort Hays Limestone Member of Niobrara Chalk (Upper Cretaceous), West-Central Kansas. The University of Kansas. Paleontological Contributions 53, 1-41.

Frey, R.W., Curran, A.H., Pemberton, G.S., 1984. Tracemaking activities of crabs and their environmental significance: the ichnogenus Psilonichnus. Journal of Paleontology 58, 511-528.

Fu, S., 1991. Funktion. Verhalten und Einteilung fucoider und lophoctenoider Lebensspuren. Courier Forschungsinstitut Senckenberg 135, 1-79.

Fürsich, F.T., 1973. A revision of the trace fossils Spongeliomorpha, Ophiomorpha and Thalassinoides. Neues Jahrbuch für Geologie und Paläontologie, Monatshefte 12, 719-735.

Galbrun, B., Gardin, S., 2004. New chronostratigraphy of the CretaceousPaleogene boundary interval at Bidart (France). Earth and Planetary Science Letters 224, 19-32.

Gallala, N., Zaghbib-Turki, D., Arenillas, I., Arz, J.A., Molina, E., 2009. Catastrophic mass extinction and assemblage evolution in planktic foraminifera across the Cretaceous/Paleogene $(\mathrm{K} / \mathrm{Pg})$ boundary at Bidart $(\mathrm{SW}$ France). Marine Micropaleontology 72, 196-209.

Gardin, S., 2002. Late Maastrichtian to early Danian calcareous nannofossils at Elles (Northwest Tunisia). A tale of one million years across the K-T boundary. Palaeogeography, Palaeoclimatology, Palaeoecology 178, 211-231.

Gardin, S., Monechi, S., 1998. Palaeoecological change in middle to low latitude calcareous nannoplankton at the Cretaceous/Tertiary boundary. Bulletin de la Société géologique de France 169, 709-723.

Gorostidi, A., Lamolda, M.A., 1995. La nanoflora calcárea y el tránsito KT de la sección de Bidart (SW de Francia). Revista Española de Paleontología extraordinario $153-168$.

Haslett, S.K., 1994. Planktonic foraminiferal biostratigraphy and paleoceanography of the Cretaceous-Tertiary boundary section at Bidart South-west France. Cretaceous Research 15, 179-192.

Henriksson, A.S., 1996. Calcareous nannoplankton productivity and succession across the Cretaceous-Tertiary boundary in the Pacific (DSDP Site 465) and Atlantic (DSDP Site 527) Oceans. Cretaceous Research 17, 451-477.

Hildebrandt-Habel, T., Willems, H., Versteegh, G.J.M., 1999. Variations in calcareous dinoflagellate associations from the Maastrichtian to Middle Eocene of the western South Atlantic Ocean (São Paulo Plateau, DSDP Leg 39 Site 356). Review of Palaeobotany and Palynology 106, 57-87.

Keighley, D.G., Pickerill, R.K., 1995. The ichnotaxa Palaeophycus and Planolites: historical perspectives and recommendations. Ichnos 3, 301-309.

Keller, G., 1988. Extinction, survivorship and evolution of planktic foraminifera across the Cretaceous/Tertiary boundary at El Kef, Tunisia. Marine Micropaleontology 13, 239-263.

Keller, G., Li, L., Macleod, N., 1995. The Cretaceous/Tertiary boundary stratotype section at El Kef, Tunisia: how catastrophic was the mass extinction? Palaeogeography, Palaeoclimatology, Palaeoecology 119, 221-254.

Kotake, N., 1989. Paleoecology of the Zoophycos producers. Lethaia 22, 327-341.

Kotake, N., 1991a. Packing process for filling material in Chondrites. Ichnos 1, 277-285. 
Kotake, N., 1991b. Non-selective surface deposit feeding by the Zoophycos producers. Lethaia 24, 379-385.

Kotake, N., 1992. Deep-sea echiurans: possible producers of Zoophycos. Lethaia 25, 311-316.

Kotake, N., 1994. Population paleoecology of the Zoophycos-producing animal. Palaios 9, 84-91.

Koutsoukos, E.A.M., 2005. The K-T Boundary. In: Koutsoukos, E.A.M. (Ed.), Applied Stratigraphy. Springer, Dordrecht, pp. 147-161.

Kring, D.A., 2007. The Chicxulub impact event and its environmental consequences at the Cretaceous-Tertiary boundary. Palaeogeography, Palaeoclimatology, Palaeoecology 255, 4-21.

Lamolda, M.A., Melinte, M.C., Kaiho, K., 2005. Nannofloral extinction and survivors across the K/T boundary at Caravaca, southeastern Spain. Palaeogeography, Palaeoclimatology, Palaeoecology 224, 27-52.

Locklair, R.E., Savrda, C.E., 1998. Ichnology of rhythmically bedded Demopolis chalk (Upper Cretaceous Alabama): implications for paleoenvironment, depositional cycle origins, and tracemaker behavior. Palaios 13, 423438.

Löwemark, L., Lin, I.T., Wang, C.H., Huh, C.A., Wei, K.Y., Chen, C.W., 2004. Ethology of the Zoophycos-producer: arguments against the gardening model from $\delta^{13} \mathrm{C}_{\mathrm{org}}$ evidences of the spreiten material. TAO 15, 713-725.

MacEachern, J.A., Burton, J.A., 2000. Firmground Zoophycos in the Lower Cretaceous Viking formation Alberta: A distal expression of the Glossifungites ichnofacies. Palaios 15, 387-398.

Mai, H., Speijer, R.P., Schulte, P., 2003. Calcareous index nannofossils (coccoliths) of the lowermost Paleocene originated in the late Maastrichtian. Micropaleontology 49, 189-195.

McBride, E.F., Picard, D.M., 1991. Facies implications of Trichichnus and Chondrites in turbidites and hemipelagites, Marnoso-Arenacea Formation (Miocene), Northern Apennines Italy. Palaios 6, 281-290.

Minoletti, F., de Rafelis, M., Renard, M., Gardin, S., 2004. Remaniement des nannofossiles calcaires maastrichtiens dans les sédiments du Danien basal de Bidart (France) : arguments isotopiques (carbone et oxygène). Revue de Micropaléontologie 47, 145-152.

Minoletti, F., de Rafelis, M., Renard, M., Gardin, S., Young, J., 2005. Changes in the pelagic fraction carbonate sedimentation during the CretaceousPaleocene transition: contribution of the separation technique to the study of Bidart section. Palaeogeography, Palaeoclimatology, Palaeoecology 216, 119-137.

Molina, E., Alegret, L., Arenillas, I., Arz, J.A., Gallala, N., Hardenbol, J., von Salis, K., Steurbaut, E., Vandenberghe, N., Zaghbib-Turki, D., 2006. The Global Boundary Stratotype Section and Point for the base of the Danian Stage (Paleocene, Paleogene, "Tertiary", Cenozoic) at El Kef Tunisia Original definition and revision. Episodes 29, 263-373.

Molina, E., Arenillas, I., Arz, J.A., 1998. Mass extinction in planktic foraminifera at the Cretaceous/Tertiary boundary in subtropical and temperate latitudes. Bulletin de la Société géologique de France 169, 351-363.

Nelson, B.K., Macleod, G.K., Ward, P.D., 1991. Rapid change in strontium isotopic composition of sea water before the Cretaceous/Tertiary boundary. Nature 351, 644-647.

Orue-Etxebarría, X., Apellaniz, E., Baceta, J.I., Coccioni, R., Di Leo, R., Dinares Turell, J., Galeotti, S., Monechi, S., Nuñez-Betelu, K., Pares, J.M., Payros, A., Pujalte, V., Samsó, J.M., Serra-Kiel, J., Schmitz, B., Tosquella, J., 1996. Physical and biostratigraphic analysis of two prospective Paleocene-Eocene Boundary Stratotypes in the intermediate-deep water Basque Bas the Trabakua Pass Ermua sections. Neues Jahrbuch für Geologie und Paläontologie Abhandlungen 201, 179-242.

Olivero, D., Gaillard, C., 2007. A constructional model for Zoophycos. In: Miller III, W. (Ed.), Trace Fossils: Concepts, Problems, Prospects. Elsevier, Amsterdam, pp. 466-477.

Osgood, R.G., 1970. Trace fossils of the Cincinnati Area. Palaeontographica Americana 6, 193-235.

Pemberton, G.S., Frey, R.W., 1982. Trace fossil nomenclature and the Planolites-Palaeophycus dilemma. Journal of Paleontology 56, 843-881.

Perch-Nielsen, K., 1979. Calcareous nannofossils at the Cretaceous/Tertiary boundary near Biarritz France. In: Christensen, W.K., Birkelund, T. (Eds.), Cretaceous-Tertiary Boundary Events. University of Copenhagen, Copenhagen, pp. 151-153.
Perch-Nielsen, K., McKenzie, J., He, Q., 1982. Biostratigraphy and isotope stratigraphy and the catastrophic extinction of calcareous nannoplankton at the Cretaceous/Tertiary boundary. In: Silver, L.T., Schultz, P.H. (Eds.), Geological implications of impacts of large asteroids and comets on the earth. Geological Society of America, Special Paper 190, pp. 353-371.

Pervesler, P., Uchman, A., 2004. Ichnofossils from the type area of the Grund Formation (Miocene Lower Badenian) in northern Lower Austria (Molasse Basin). Geologica Carpathica 55, 103-110.

Pospichal, J.J., 1994. Calcareous nannofossils at the K-T boundary El Kef: no evidence for stepwise, gradual, or sequential extinctions. Geology 22, 99102.

Pospichal, J.J., 1996. Calcareous nannoplankton mass extinction at the Cretaceous/Tertiary boundary: An update. In: Ryder, R., Fastovsky, D., Gartner, S. (Eds.), The Cretaceous-Tertiary Event and Other Catastrophes in Earth History. Geological Society of America Special Paper 307, pp. 335-360.

Pospichal, J.J., Wise, S.W., 1990. Calcareous nannofossils across the K/T boundary, ODP Hole 690C, Maud Rise, Weddell Sea. Proceedings of the Ocean Drilling Program, Scientific Results 113, College Station, TX 515532.

Pospichal, J.J., Wise, S.W., Asaro, F., Hamilton, N., 1990. The effects of bioturbation across a biostratigraphically complete, high southern latitude Cretaceous/Tertiary boundary. Geological Society of America, Special Paper 247, 497-507.

Pujalte, A., Baceta, J.I., Orue-Etxebarria, X., Payros, A., 1998. The Paleocene of the Basque Country, W Pyrenees facies sequence development in a deepwater starved basin. In: de Graciansky, P.C., Hardenbol, J., Jacquin, T., Vail, P.R. (Eds.), Mesozoic and Cenozoic Sequence Stratigraphy of European Basins. SEPM Concepts in Sedimentology and Paleontology 60 Tulsa, pp. 311-325.

Renard, M., Delacotte, O., Letolle, R., 1982. Le strontium et les isotopes stables dans les carbonates totaux de quelques sites de l'atlantique et de la Téthys. Bulletin de la Société géologique de France 24, 519-534.

Rodríguez-Tovar, F.J., 2005. Fe-oxide spherules infilling Thalassinoides burrows at the Cretaceous-Paleogene (K-P) boundary: evidence of a nearcontemporaneous macrobenthic colonization during the K-P event. Geology $33,585-588$.

Rodríguez-Tovar, F.J., Martínez-Ruiz, F., Bernasconi, S.M., 2004. Carbon isotope evidence for the timing of the Cretaceous-Palaeogene macrobenthic colonisation at the Agost section (southeast Spain). Palaeogeography, Palaeoclimatology, Palaeoecology 203, 65-72.

Rodríguez-Tovar, F.J., Uchman, A., 2004. Trace fossils after the K-T boundary event from the Agost section SE Spain. Geological Magazine 141, 429-440.

Rodríguez-Tovar, F.J., Uchman, A., 2008. Bioturbational disturbance of the Cretaceous-Palaeogene (K-Pg) boundary layer: implications for the interpretation of the K-Pg boundary impact event. Geobios 41, 661-667.

Romein, A.J.T., Willems, H., Mai, H., 1996. Calcareous nannoplankton of the Geulhemmerberg K/T boundary section. Maastrichtian type area, the Netherlands. Geologie en Mijnbouw 75, 231-238.

Schlirf, M., 2000. Upper Jurassic trace fossils from the Boulonnais (northern France). Geologica et Palaeontologica 34, 145-213.

Seilacher, A., 1990. Aberration in bivalve evolution related to photo- and chemosymbiosis. Historical Biology 3, 289-311.

Seilacher, A., 2007. Trace Fossil Analysis. Springer, Berlin-Heidelberg.

Seyve, C., 1984. Le passage Crétacé-Tertiaire à Pont Labau. Bulletin des Centres de Recherches Exploration-Production Elf-Aquitaine 8, 385-423.

Seyve, C., 1990. Nannofossil biostratigraphy of the Cretaceous-Tertiary boundary in the French Basque Country. Bulletin des Centres de Recherches Exploration-Production Elf-Aquitaine 14, 553-572.

Smit, J., 1990. Meteorite impact, extinctions and the Cretaceous-Tertiary boundary. Geologie en Mijnbouw 69, 187-204.

Smit, J., Romein, A.J.T., 1985. A sequence of events across the CretaceousTertiary boundary. Earth and Planetary Science Letters 74, 155-170.

Smit, J., Ten Kate, W.G.H.Z., 1982. Trace-element patterns at the CretaceousTertiary boundary: consequences of a large impact. Cretaceous Research 3, 307-332.

Sternberg, G.K., 1833. Versuch einer geognostisch-botanischen Darstellung der Flora der Vorwelt. IV Heft. C.E. Brenck. Regensburg. 
Tantawy, A.A., 2003. Calcareous nannofossil biostratigraphy and paleoecology of the Cretaceous-Tertiary transition in the central eastern desert of Egypt. Marine Micropaleontology 47, 323-356.

Thibault, N., Minoletti, F., Gardin, S., Renard, M., 2004. Morphometry of selected calcareous nannofossils across the Cretaceous-Paleocene boundary at the Bidart (France) and Elles (Tunisia) sections. Bulletin de la Société géologique de France 175, 399-412.

Thierstein, H.R., 1981. Late Cretaceous nannoplankton and the change at the Cretaceous-Tertiary boundary. SEPM Special Publication 32, Tulsa 355-394.

Thierstein, H.R., Okada, H., 1979. The Cretaceous/Tertiary boundary event in the North Atlantic. Initial Reports of the Deep Sea Drilling Project 43, U.S. Government Printing Office, Washington 601-616.
Uchman, A., 1995. Taxonomy and palaeoecology of flysch trace fossils: The Marnoso-Arenacea formation and associated facies (Miocene, Northern Apennines Italy). Beringeria 15, 3-115.

Uchman, A., 1999. Ichnology of the Rhenodanubian flysch (Lower CretaceousEocene) in Austria and Germany. Beringeria 25, 65-171.

Werner, F., Wetzel, W., 1981. Interpretation of biogenic structures in oceanic sediments. Bulletin de l'Institut de Géologie du Bassin d'Aquitaine 31, 275288.

Wetzel, A., Werner, F., 1981. Morphology and ecological significance of Zoophycos in deep-sea sediments off NW Africa. Palaeogeography, Palaeoclimatology Palaeoecology 32, 185-212. 